\title{
Reduction of Treated Water Use through Application of Rainwater Tanks in Households
}

\author{
Marek Madzia' \\ 1 Institute of Environmental Protection and Engineering, Faculty of Materials, Civil and Environmental \\ Engineering, University of Bielsko-Biala, Willowa 2, 43-309 Bielsko-Biala, Poland \\ e-mail:mmadzia@ath.bielsko.pl
}

\begin{abstract}
The civilization progress entails an increasing demand for water. There are many different technologies for collecting water from alternative sources. An efficient and cost-effective solution is to use small tanks for rainwater runoff from rooftops. In this way, the harvested water can be successfully used to flush toilets, which stands for 30 percent of water consumption in households. The capacity of water tanks depends on the technical and economic possibilities. Using a dual flush system in toilets that allows for both rainwater and mains water usage can lead to a significant reduction in the tank size. In Bielsko-Biała, given its environment, one-family dwellings, a rainwater tank with a capacity of only $0.25 \mathrm{~m}^{3}$ per person and a roof area of $30 \mathrm{~m}^{2}$ per person, it is possible to save almost 80 percent of treated mains water used in toilet flushing. It constitutes over $10 \mathrm{~m}^{3}$ of water per person per year. A nomogram made for choosing the right tank according to the roof area and tank capacity allows assessing the possibilities in terms of drinking water savings in any building in the environment of Bielsko-Biała.
\end{abstract}

Keywords: rainwater tank, rainwater harvesting, water savings

\section{INTRODUCTION}

The progress in urbanization contributes to irreversible changes in the environment. Building new houses, roads, parking lots and other infrastructure elements means that impermeable surfaces are continuously increasing, which on one hand accelerates the water outflow from the drainage basin and increases the flood risk, as well as lowers the level of water table through infiltration decrease, and consequently, the water resources on the other hand. Although the urban areas are often characterized by water shortages, rainwater is paradoxically treated as a threat and rather than a precious source of water [1].

Nowadays, more and more attention is drawn to the possibilities of storing water in drainage basins. With very small devices used in households, this phenomenon can be described as small scale water retention. These are objects and devices of different kinds that allow us to partially retain rainwater. There are devices used for surface infiltration, such as infiltration surfaces, permeable ditches, basins and infiltration recipients or devices for underground infiltration - absorbing wells, swales, leaching boxes and chambers [2].

The simplest solution is to collect water from the roof surfaces. Rainwater is drained from a rooftop through outlet pipes with filters, and then is collected in a recipient. It is delivered to an internal water system through a pump, after a proper cleanup.

Apart from households, rainwater can be collected and used in commercial and public buildings, for example in hotels, at gas stations, as well as for municipal purposes, such as watering urban greenery or washing streets. Depending on the final purpose of the collected rainwater, we have to oversee appropriate ways of water treatment and disinfection. Rainwater should be stored at low temperature and without exposure to sunlight, in order to limit the development of microorganisms and algae. The tanks available on the market come in different shapes and sizes and are made 
of different materials: plastics, concrete or steel. The polyethylene tanks are the most common. They should be equipped with an emergency overflow, so that a prospective surplus of rainwater can be drained into soil or directed to a storm water drain. We should also take into consideration a possibility of an extra supply from a water supply network [6].

The systems that make use of rainwater are very popular in Germany, Great Britain, Australia or Japan. These countries have norms regulating the quality of water required for toilet flushing, for instance [2]. These solutions have an invaluable impact for the environment, although they are not cheap and have a rather long payback period. However, these systems became popular owing to a wide array of subsidies and different tax exemptions as well as an appropriate education of societies [1].

A tank for collecting rainwater constitutes the most expensive element of the system. This is why a careful selection of the best tank size is crucial. The selection process normally includes simplified methods of determining tank volume, based on one of the following dependencies:

- 5 percent of average annual rainfall,

- 14 to 30 days of rainwater demand for flushing toilets, 3-month period for garden watering,

- $1 \mathrm{~m}^{3}$ of tank for $25 \mathrm{~m}^{2}$ of roof from which rainwater is harvested [5].

The capacity of such a tank is individually adjusted to the predicted rainfall volume and water demand. Tank oversizing unnecessarily increases the investment costs and lengthens the water retention time, which significantly deteriorates its quality. In turn, a tank which is smaller than required results in more frequent usage of the mains water supply.

\section{METHODOLOGY}

In order to reduce the usage of water, attempts were made to adopt the solution which is as simple as possible, the one that would be inexpensive and efficient at the same time. As the tank is the most expensive element of rainwater management in households, the approach was to achieve satisfactory water savings with a rather small tank.

In households, the greatest opportunities for using rainwater come with toilet flushing, where as much as 30 percent of water is used. According to the available literature data, the water usage in toilets equals to approximately 18 to $40 \mathrm{dm}^{3}$ per person per day $[2,3]$. According to this paper's author's own observations, the usage equals to 22-34 $\mathrm{dm}^{3}$ per person per day. In practice, the actual usage depends on many different factors. It includes the technical solutions applied to the flushing system (single button, start-stop button, double button, regulated water flushing) or individual preferences of the user (using stop or dual flush button, state of health, time spent away from home). Taking into consideration the average norms of water consumption in Poland, one person uses 80 to $160 \mathrm{dm}^{3}$ of water per day [4]. Therefore, $30 \%$ of average value equals to $36 \mathrm{dm}^{3}$ per person per day. If this value is included in the analysis, in one year one person consumes $13.1 \mathrm{~m}^{3}$ of water.

While choosing the right rainwater tank, the crucial question is how the tank is supplied, which is conditioned by the volume and frequency of rainfall. Therefore, the values of daily rainfall were analyzed and the inflows to the tank were determined. The calculations were based on a 30-year time period of daily precipitation (19892018) for a weather station in Bielsko-Biała. The data was supplied by the Institute of Meteorology and Water Management - National Research Institute (IMGW-PIB). Having analyzed the information, the following can be concluded:

1. Average annual rainfall for the time period in question equals to $983.4 \mathrm{~mm}$, and the highest total precipitation was in 2010 with $1478.1 \mathrm{~mm}$, whereas in 1993 it was practically half this value with $738.8 \mathrm{~mm}$.

2. Daily rainfall reached its peak on 16 May 2010 with $162.7 \mathrm{~mm}$. The highest monthly precipitation was noted in May 2010 (511.5 mm). If we start counting on 3 May 2010, in 30 days the rainfall was as high as $564 \mathrm{~mm}$, which equals to 57.4 percent of average rainfall per year.

3. The longest period without rainfall was 38 days and started on 26 October 2011. For a period of 60 days, the lowest rainfall was $17.0 \mathrm{~mm}$ starting on 21 October 2011, and for a period of 90 days $47.1 \mathrm{~mm}$ starting from 19 December 1990.

Given the information above, an autonomous toilet flushing system based solely on rainwater would require a very high-capacity tank. Long periods without rainfall and with little rainfall confirm this. 
In order to determine the roof runoff, numbers from the 30-year interval of daily rainfall were reduced by the flow coefficient value $(C v) \psi=0.9$ (average value according to PN-92/B-01707) applied for inclined roofs. Very small values up to $0.2 \mathrm{~mm}$ were left out assuming that in these cases the roof runoff would not occur.

Large underground tanks are applied mainly in new investments at the design stage. The possibilities of including the installations with rainfall are much greater then. In the case of the already existing buildings, it can be difficult to find a place for such a tank. It involves complex ground works as well as interference in the development of the terrain around the property.

As the solution should be simple and budgetfriendly, placing a tank inside a building was also taken into consideration (Figure 1). In this case, the ground works are limited to building an appropriate inspection chamber with a basket and water draining to a tank in the basement of the building. The tank can be purchased second-hand (for instance a typical "Mauzer" tank with a $1 \mathrm{~m}^{3}$ capacity). In order to avoid the development of algae, the tank should be made of an opaque material or be placed in a dark room. Any interference in the water and sewer installation in the building is limited to passing a separate pipe from the tank through a pump (hydrophore tank) to the flushing system. An automatic system of switching between rainwater system and mains water supply system (the so-called dual system) in case of water shortage in the tank is a necessary element in the discussed solution. In such case, the tank is filled with the treated water from the pipes, for instance with a float valve or a solenoid valve with a float sensor.

Another possible solution is to use a 3-way valve which, in case of water shortage, can automatically switch between water systems and cut off pump drive through a controlling device. In this case, the pump does not need to operate when the water comes from the pipeline. In order not to let rainwater mix with treated water, an anti-pollution check valve should be applied to the treated water pipe before a three-way valve (Figure 1). The pipes should be appropriately marked. If there is no basement, theoretically it is also possible to install tanks in the attic. The tank can be supplied with a collector attached to the gutter, and the flushing cistern can be fed with tank water even by gravity.

In terms of roof surface and number of inhabitants, single family dwellings differ quite

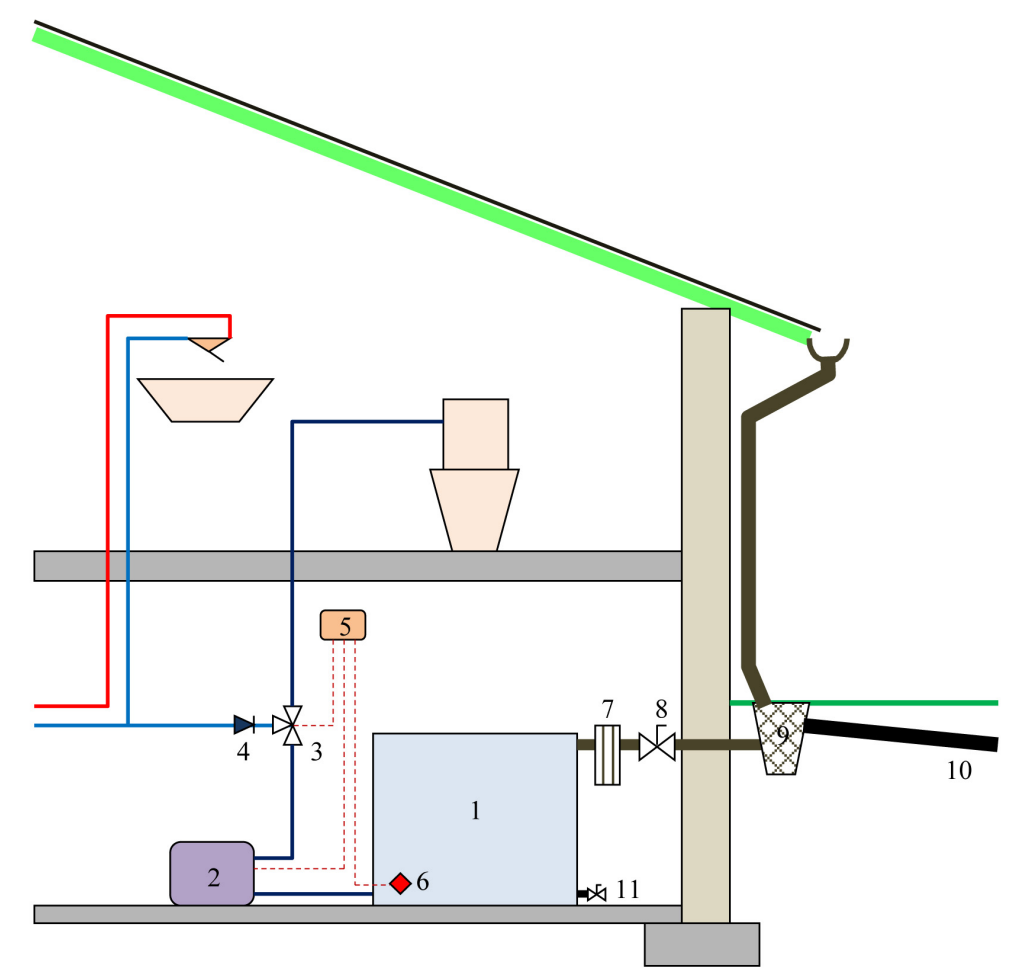

Figure 1. Scheme of economic utilization of rainwater with a tank inside a building (own study)

Description: 1 - rainfall tank, 2 - pump, 3 - three-way valve, 4 - anti-pollution valve, 5 - controller, 6 - water level detector, 7 - filter, 8 - latch, 9 - inspection chamber with basket, 10 - surplus runoff, 11 - drain valve 
significantly. As a result, the analysis is based on a single inhabitant, which means that the roof surface and the tank capacity as unit values refer to one person. Assuming that a typical singlefamily house has a roof surface of $120 \mathrm{~m}^{2}$ and is inhabited by 4 persons, then there are $30 \mathrm{~m}^{2}$ of roof surface per person. If we apply a typical tank with a $1 \mathrm{~m}^{3}$ capacity, then there will be $250 \mathrm{dm}^{3}$ per person.

\section{STUDY RESULTS}

The savings in the treated water were determined on the basis of daily simulations over a period of thirty years (1989-2018), and the following assumptions were made:

1. The savings of the treated water will be a result of supplying flushing cisterns with rainwater from a tank.

2. In case of water shortage, the tank is supplied with mains water - the so-called dual system.

3. The tank is supplied according to a reduced value of daily rainfall and a given roof surface (as seen in a floor plan).

4. Water runoff from the tank was adopted as fixed daily value of $36 \mathrm{dm}^{3}$ per person.

At the initial stage, an analysis concerning the effectiveness of the system in given years (Figure 2) was made. The calculations were based on one person per $30 \mathrm{~m}^{2}$ of roof and a tank with $0.25 \mathrm{~m}^{3}$ capacity. Given these values, the efficiency of the system in meeting the demand for rainwater varied between 70 percent in 2018 and 87.5 percent in 2001 . While comparing the total annual precipitation with the achieved demand coverage for the rainwater in the toilet flushing tanks, a close correlation was not achieved. For instance, in 2010, when the annual precipitation was the highest, the demand was met by 82.3 percent, whereas in 1993, when the annual precipitation was the lowest, it was comparable with the level of 81.2 percent. Average demand coverage for a period of 30 years was at the level of 79.5 percent. In practice, it means that one person can generate savings of nearly $10,5 \mathrm{~m}^{3}$ in treated water per year, even with such a small tank $\left(0.25 \mathrm{~m}^{3}\right)$. It should be nevertheless noted that an average use of rainfall would be at the level of 40.3 percent. However, when compared to specific years, the usage of rainfall is practically inversely proportional to annual precipitation, which is obvious. In 1993, rainfall was used by 53.7 percent during the lowest precipitation $(738.8 \mathrm{~mm})$, and by 27.1 percent during the highest precipitation in $2010(1478 \mathrm{~mm})$.

A simulation of tank operation in relation to rainfall was based on an example of two years, when the supply for rainfall was marked with extreme values. In 2018, the lowest value of 70 percent (Figure 3) and in 2001 the highest value of 87.5 percent (Figure 4) were noted.

At the next stage, an average efficiency of the proposed system with a changing tank capacity was analyzed (Figure 5). The analysis shows that already a capacity of $0.2 \mathrm{~m}^{3}$ per person allows to meet the demand for rainwater by 75 percent, whereas a capacity of $0.5 \mathrm{~m}^{3}$ per personby 91 percent. Here, using a tank capacity in a cost-effective option seems to be optimal, given that even with the capacity of $2.0 \mathrm{~m}^{3}$ per person a full coverage of rainwater demand cannot be achieved (99.5 percent). At the same time the usage of rainwater in relation to the increasing tank capacity is not directly proportional and achieved a maximum of 49.4 percent for a tank with the capacity of $2 \mathrm{~m}^{3}$ per person.

The presented analysis was based on an average roof surface of $30 \mathrm{~m}^{2}$ per person as a

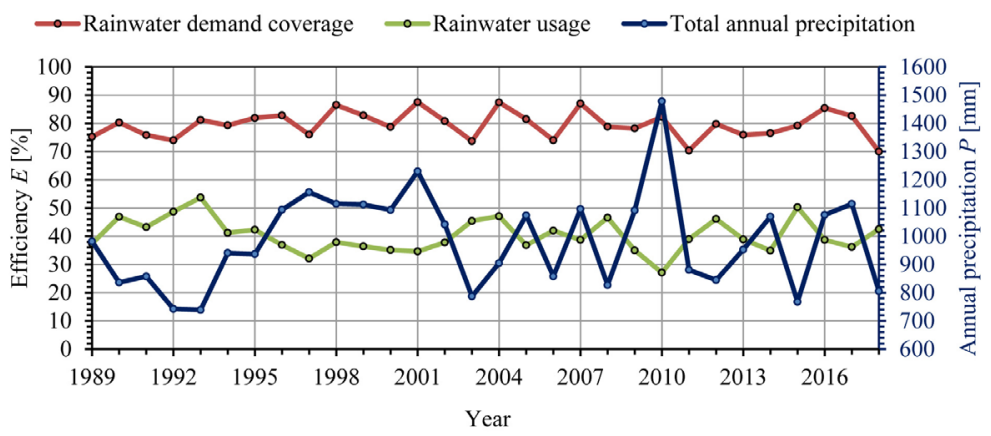

Figure 2. Effectiveness of supplying toilet cisterns with rainfall compared to annual precipitation in Bielsko-Biała (assumptions: roof surface $A_{1}=30 \mathrm{~m}^{2}$ per person; tank capacity $V_{I}=0,25 \mathrm{~m}^{3}$ capacity per person) 

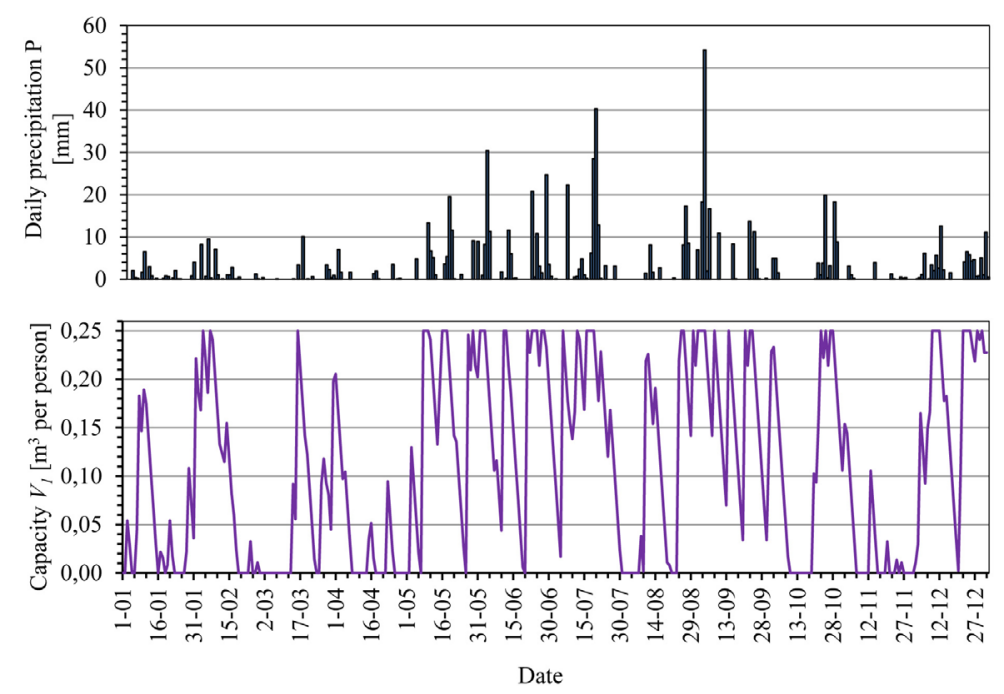

Figure 3. Simulation of tank work in 2018 compared to rainfall (assumptions: roof surface $A_{1}=30 \mathrm{~m}^{2}$ per person; tank capacity $V_{1}=0.25 \mathrm{~m}^{3}$ per person)
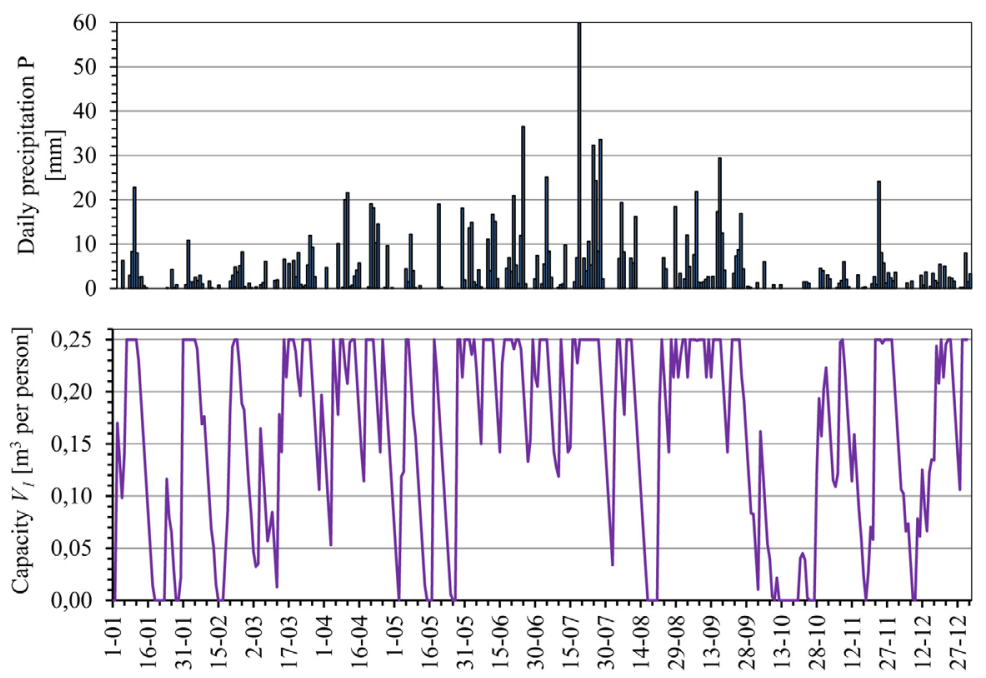

Date

Figure 4. Simulation of tank work in 2001 compared to rainfall (assumptions: roof surface $A_{1}=30 \mathrm{~m}^{2}$ per person; tank capacity $V_{1}=0.25 \mathrm{~m}^{3}$ per person)

representative value for one-family dwellings. However, as it has already been noted, this value can differ significantly depending on a specific case. Therefore, a nomogram was created to select a tank capacity (Figure 6) that could also be used in terraced houses and multi-family housing. The choice of tank capacity is based on the roof size. While choosing the rainwater demand coverage for toilet flushing from an appropriate curve, the tank capacity unit value is obtained. This value should be then multiplied by the number of inhabitants. Assuming that one person on average uses $13.1 \mathrm{~m}^{3}$ of water per year for toilet flushing, the nomogram can help determine real savings in the treated water for a specific case.

\section{CONCLUSIONS}

On the basis of the conducted research the following conclusions can be drawn:

1. Applying rainfall harvesting system for flushing toilets in households, even with small tanks of $0.25 \mathrm{~m}^{3}$ per person generates the treated water savings of approximately $10 \mathrm{~m}^{3}$ per person per year.

2. The developed nomogram of tank selection allows determining the savings in the treated water that is used for toilet flushing according to the roof area and rainwater tank capacity in Bielsko-Biała. 


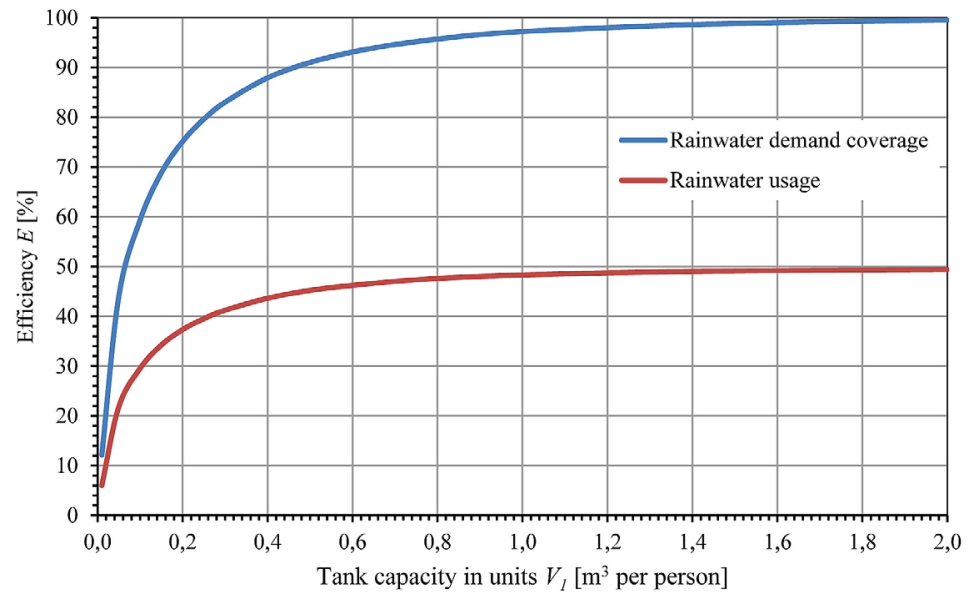

Figure 5. Coverage of rainwater demand for toilet flushing compared to tank capacity in units in Bielsko-Biała (assumptions: roof area $A_{1}=30 \mathrm{~m}^{2}$ per person)

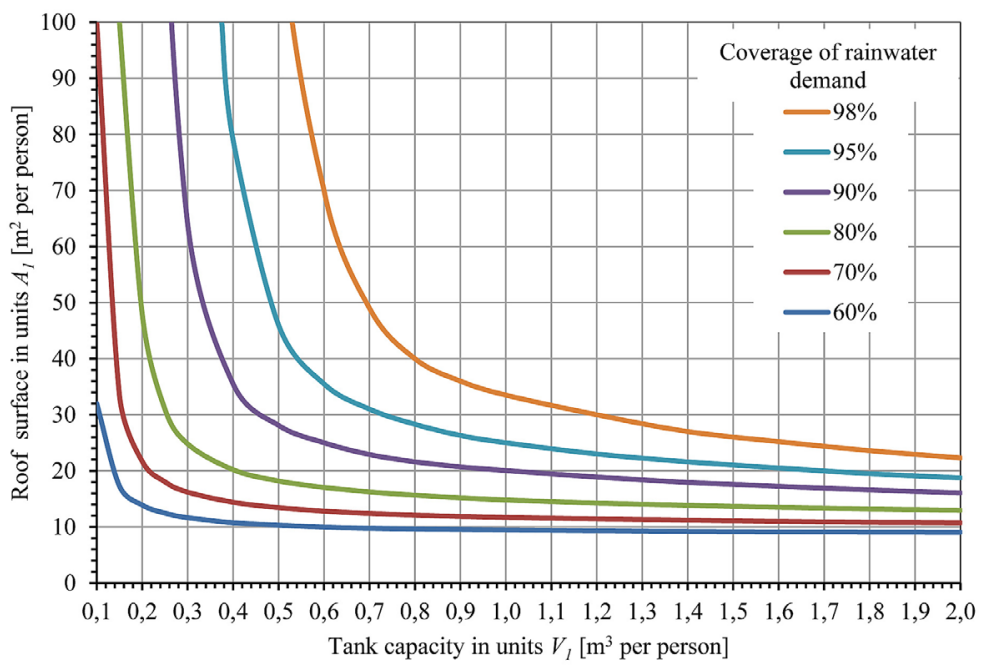

Figure 6. Nomogram depicting tank selection in Bielsko-Biała, considering the coverage of water demand for toilets in percentage

3. Small rainwater tanks can be installed inside buildings, which lowers the costs of building rainwater harvesting systems and at the same time guarantees real savings in the treated water.

4. The selection process of rainwater tank volume should be based on the demand coverage of daily precipitation from a nearby weather station and sample water usage from the tank.

\section{REFERENCES}

1. Domènech L., Saurí D. 2011. A comparative appraisal of the use of rainwater harvesting in single and multi-family buildings of the Metropolitan Area of Barcelona (Spain): social experience, drinking water savings and economic costs. Journal of Cleaner Production. Vol.19, 598-608.
2. Królikowska J., Królikowski A. 2012. Wody opadowe. Odprowadzanie, zagospodarowanie, podczyszczanie i wykorzystanie. Wyd. Seidel-Przywecki, Warszawa.

3. Merc K., Stępniak L. 2015. Instalacje dualne jako alternatywa dla tradycyjnych instalacji wodociągowokanalizacyjnych. Inżynieria i Ochrona Środowiska 18/4, 549-562.

4. Minister of Infrastructure Regulation of 14 January 2002 regarding determination of average norms of water usage (Dz.U. $2002 \mathrm{Nr} 8$ poz.70).

5. Sakson G. (2010): Wykorzystanie wód opadowych w budynkach. Rynek Instalacyjny 5/2010: 11-15.

6. Wociechowska E. 2018. Zastosowanie zielonej infrastruktury do ograniczenia zanieczyszczenia wód powierzchniowych w zlewni miejskiej. Monografie Komitetu Inżynierii Środowiska Polskiej Akademii Nauk. vol. 145, Gdańsk. 